Omni-Akuatika, 12 (3): 29-46, 2016
ISSN: 1858-3873 print / 2476-9347 online
Research Article

\title{
Jasa Ekosistem Lamun Bagi Kesejahteraan Manusia
}

\author{
Yudi Wahyudin ${ }^{1,2}$, Tridoyo Kusumastanto ${ }^{2,3}$, Luky Adrianto ${ }^{2,4}$, Yusli Wardiatno ${ }^{4}$ \\ ${ }^{1}$ Program Studi Ekonomi Sumberdaya Kelautan Tropika IPB, Gedung Fakultas Ekonomi dan Manajemen, \\ Kampus IPB Dramaga Bogor \\ ${ }^{2}$ Pusat Kajian Sumberdaya Pesisir dan Lautan IPB, Kampus IPB Baranangsiang, Jl. Raya Pajajaran Bogor \\ ${ }^{3}$ Fakultas Ekonomi dan Manajemen IPB, Gedung Fakultas Ekonomi dan Manajemen, Kampus IPB Dramaga \\ Bogor \\ ${ }^{4}$ Fakultas Perikanan dan IImu Kelautan IPB, Gedung Fakultas Perikanan dan IImu Kelautan, Kampus IPB \\ Dramaga Bogor
}

*Corresponding author : yudi.wahyudin@pksplipb.or.id

\begin{abstract}
The purpose of this study was to determine the typology, seagrass ecosystem function and services that are useful for human well-being. This research was conducted by using literatures survey of some scientific documents and analyzed qualitatively and described to obtain a comprehensive overview in accordance with purposes of this research. The results of this study shows that seagrass ecosystem provides the benefits of ecosystem services are valuable and needed humans to meet their needs and well-being, both ecologically, socially, and economically. Those ecosystem services include the following: (i) provisioning services that one of them shown by the production of a protein source necessary for mandkind, (ii) regulating services, one of which is shown by role of seagrass in maintaining the stability of white sand beaches from abrasion, (iii) cultural services, one one which is shown by the role of seagrass in making the surrounding area as a place for recreation, especially recreational fishing, and (iv) supporting services, one of which is shown by the role of seagrass in the process of supplying oxygen and nutrient cycling in the waters of the needs of fish and biota surrounding. All the ecosystem services provided to be a source of life and livelihood are needed to meet the people's welfare.
\end{abstract}

Keywords : seagrass, ecosystem services, provisioning services, regulating services, cultural services, supporting services

\section{Pendahuluan}

Ekosistem lamun (seagrass) adalah salah satu komponen penting sebagai penyusun kesatuan ekosistem pesisir bersama dengan mangrove dan terumbu karang (de la Torre-Castro, 2006). Ekosistem lamun tidak terlalu banyak mendapatkan perhatian, padahal ekosistem lamun cukup menyediakan barang dan jasa yang penting (de la TorreCastro et al, 2014) dan hal ini cukup mengejutkan mengingat bahwa lamun mempunyai distribusi yang cukup menyebar di seluruh dunia (den Hartog, 1970). Walaupun secara lokal, sosial-ekologis lamun telah dianggap penting (de la Torre-Castro and Ronnback, 2004), akan tetapi pada kenyataannya kepentingan ini masih difahami hanya sebagai bagian dari sistem sosial- ekologi dunia (Cullen-Unsworth et al, 2014; de la Torre-Castro et al, 2014).

Habitat lamun mempunyai jasa ekosistem yang cukup beragam, khususnya terkait dengan jasa pendukung (supporting services) dan sebagai penyedia daerah asuhan (nursery ground), tempat mencari makan (feeding ground), sirkulasi nutrien dan lain-lain (Costanza et al, 1997), bahkan lamun mempunyai keterkaitan yang kuat dan berasosiasi dengan beberapa organisme khas dan unik di sekitarnya, seperti dugong, kuda laut dan penyu laut, yang kesemuanya mempunyai ketergantungan terhadap ekosistem lamun, namun demikian tetap saja penelitian dan perhatiannya tentang ekosistem lamun masih jarang dibuat dan masih belum optimal dilakukan (Hughes et al, 2009). Dengan segenap jasa ekosistem yang diberikan ekosistem lamun tersebut, maka 
tidaklah mengherankan bilamana kemudian nilai ekonomi total ekosistem lamun lebih tinggi dibandingkan dengan nilai ekonomi total dari ekosistem terumbu karang dan ekosistem mangrove (Costanza, 1997).

Pemahaman moneter sumberdaya alam dan lingkungan sangat berguna untuk mempromosikan penggunaan sumberdaya lokal yang berkelanjutan dalam jangka panjang (Unsworth et al, 2010). Penggunaan matrik aliran manfaat dan biaya dapat memberikan indikasi akan adanya nilai finansial dari sumberdaya alam dan lingkungan saat ini dan pemangku kepentingan lokal selanjutnya dapat membuat keputusan yang tepat melalui analisis manfaat-biaya sederhana secara langsung untuk menentukan skenario pengelolaan ekosistem sumberdaya alam dan lingkungan (Pearce and Turner, 1990; Green and Tunstall, 1991).

Pengkajian informasi terhadap stakeholders mengenai status ekosistem lamun dengan melibatkan masyarakat setempat sebagai modal sosial merupakan salah satu pendekatan terbaik untuk menghasilkan keputusan efektif bagi pengelolaan sumberdaya alam dan lingkungan (Pretty, 2003), termasuk pengelolaan ekosistem lamun. Informasi yang dihasilkan dari masyarakat ini secara sederhana merupakan pendekatan dengan menggunakan konsepsi atau pemikiran bahwa manusia dengan pendidikan dan atau pengetahuan ilmiah yang relatif terbatas dapat memahami dan mempromosikan secara lebih sistematis untuk mendukung kebijakan pengelolaan sumberdaya alam dan lingkungan (Unsworth et al, 2010). Sayangnya untuk negara-negara berkembang seperti Indonesia, pemahaman dan pendekatan penentuan keputusan pengelolaan sumberdaya alam dan lingkungan dengan model seperti ini belum atau bahkan bisa juga tidak pernah dilakukan oleh pemerintah, sehingga lebih memperburuk akan maraknya kegiatan eksploitasi berlebih sehingga menyebabkan adanya kehilangan atau kepunahan sumberdaya (Unsworth and Cullen, 2010), terlebih lagi bilamana pengukuran keberhasilan implementasi pengelolaan ekosistem sumberdaya alam dan lingkungannya menghadapi berbagai kendala terkait dengan terutama penerapan kebijakan yang saling kontra produktif dengan keberlanjutan sumberdaya pulih (Souvorov, 1999), sehingga tidaklah mengherankan bilamana kemudian negara berkembang seperti Indonesia, masih belum menerima dan menganggap bahwa pengelolaan berbasis konservasi merupakan bentuk pengelolaan yang menjanjikan lebih besar manfaat bagi kesejahteraan masyarakat luas.

Fenomena tersebut di atas memberikan dampak terhadap persepsi ilmuwan yang kemudian berkesimpulan bahwa praktek pengelolaan sumberdaya alam di banyak negara berkembang sering kali tidak dilakukan secara baik dan pada gilirannya berdampak terhadap terjadinya penurunan kualitas dan kuantitas sumberdaya, termasuk ekosistem lamun. Anggapan berikutnya adalah munculnya hipotesis bahwa negara miskin yang sangat bergantung pada keberadaan sumberdaya dan mempunyai tingkat pertumbuhan penduduk yang lebih besar sangatlah rentan berdampak terhadap terjadinya degradasi dan kerusakan sumberdaya (Warford, 1989).

Pernyataan Warford (1989) tersebut sepertinya dapat dibenarkan bilamana negara berkembang, khususnya negara miskin yang masyarakatnya mempunyai tingkat ketergantungan tinggi terhadap sumberdaya alam menjadi tidak perduli terhadap upayaupaya pemanfaatan sumberdaya berkelanjutan. Masyarakat pesisir Indonesia, sebagai bagian dari rakyat sebuah negara berkembang, juga masih bertumpu pada pemanfaatan sumberdaya pesisir dan laut dalam upaya untuk memenuhi kebutuhan hidup jangka pendek (harian), bahkan sebagian dari mereka menggunakan caracara yang tidak ramah lingkungan untuk mendapatkan hasil yang lebih banyak dan lebih cepat. Akan tetapi, tidak sedikit pula komunitas lokal yang telah menjadikan pengelolaan komunal sumberdaya pesisir dan laut sebagai bagian yang tidak terpisahkan dalam pemanfaatannya.

Artikel ini diharapkan dapat menjadi jembatan bagi adanya pemahaman menyeluruh mengenai ekosistem lamun, karena ekosistem ini merupakan salah satu ekosistem utama di wilayah pesisir dan laut yang peranannya sangat penting dalam pemenuhan kebutuhan hidup dan penghidupan masyarakat, khususnya di wilayah pesisir dan pulau-pulau kecil. 
Peranan penting ekosistem lamun ini diantaranya dapat ditunjukkan oleh adanya manfaat jasa ekosistem yang disediakan lamun yang berguna dan dibutuhkan manusia, baik secara langsung maupun tidak langsung.

\section{Tipologi dan fungsi lamun}

Ekosistem pesisir, termasuk di dalamnya ekosistem lamun, merupakan sistem ekologi yang unik dan spesifik serta memerlukan pengelolaan yang spesifik agar dapat memberi sebesar-besarnya manfaat bagi masyarakat, bangsa dan Negara Kesatuan Republik Indonesia (Wahyudin dan Adrianto, 2012). Padang lamun merupakan ekosistem laut yang penting dan mampu menyediakan makanan, habitat dan daerah merupakan asuhan bagi berbagai spesies, kerang, manatee dan penyu laut (Fish and Wildlife Research Institute, 1999). Ekosistem lamun adalah satu dari tiga ekosistem utama wilayah pesisir dan mempunyai fungsi sosialekologis yang bermanfaat bagi manusia (Costanza, 1991; Freeman III, 2003; de la Torre-Castro, 2006).

Lamun (seagrass) adalah tumbuhan berbunga (Angiospermae) yang tumbuh mencolok dan sering merupakan komponen utama yang dominan di lingkungan perairan pesisir. Lamun telah sepenuhnya menyesuaikan diri untuk hidup dengan sebagian tubuhnya terbenam di dalam air laut. Jumlah jenis lamun di dunia adalah 58 jenis yang dikelompokkan ke dalam 12 marga, empat suku dan dua ordo (Kuo and McComb, 1989).

Sejak jaman dinosaurus, terdapat 3 (tiga) kelompok tumbuhan (angiosperma) yang menempati lautan, yang kemudian dikenal sebagai lamun (seagrasses). Lamun merupakan satu-satunya tumbuhan berbunga yang dapat hidup di bawah permukaan air, lebih cenderung mirip dengan tanaman teresterial teratai dan jahe daripada rumput yang sebenarnya dan mereka tumbuh pada sedimen dasar laut dengan tegak, daun memanjang, dan akar terkubur seperti rimpang (McKenzie, 2008).

$\mathrm{Di}$ perairan Indonesia dijumpai sebanyak 12 jenis lamun, yaitu: Enhalus acoroides, Halophila decipiens, Halophila spinulosa, Halophila ovalis, Halophila minor, Thalassia hemprichii, Cymodocea rotundata, Cymodocea serrulata, Halodule pinifolia, Halodule uninervis, Syringodium isoetifolium, dan Thalassodendron ciliatum. Masih ada dua jenis lamun lagi yang herbariumnya ada di Herbarium Bogoriense-Bogor, yaitu Halophila beccarcii dan Ruppia maritima yang diduga berasal dari perairan Indonesia (Kiswara, 1994). Vegetasi lamun yang lebat dapat terdiri dari suatu komunitas tunggal atau lebih membentuk padang lamun.

Padang lamun merupakan salah satu ekosistem laut dangkal yang mempunyai peranan penting dalam kehidupan berbagai biota laut serta merupakan salah satu ekosistem laut yang paling produktif. Ekosistem lamun daerah tropis dikenal tinggi produktifitasnya terutama dalam pore water dan sedimen. Lamun dapat memperoleh nutrisi, baik dari air permukaan melalui helaian daun-daunnya, maupun sedimen melalui akar dan rimpangnya (Kiswara dan Wanardi, 1994), tetapi sumber utama nutrisi lebih banyak berasal dari sedimen (lizumi et al, 1980). Padang lamun tersebar luas di perairan laut dangkal Indo Pasifik, termasuk perairan Indonesia. Indonesia yang mempunyai panjang garis pantai $81.000 \mathrm{~km}$, tentunya mempunyai padang lamun yang luas, bahkan terluas di daerah tropik (Kiswara dan Wanardi, 1994). Beberapa jenis dan penyebaran lamun di perairan Indonesia selengkapnya dapat dilihat pada Tabel 1. 
Tabel 1. Jenis dan penyebaran lamun di perairan Indonesia

\begin{tabular}{|c|c|c|c|c|c|c|}
\hline \multirow{2}{*}{ Suku } & \multirow{2}{*}{ Jenis } & \multicolumn{5}{|c|}{ Sebaran } \\
\hline & & 1 & 2 & 3 & 4 & 5 \\
\hline \multirow[t]{6}{*}{ Potamogetonaceae } & Halodule uninervis & + & + & + & + & + \\
\hline & Halodule pinifolia & + & + & + & + & + \\
\hline & Cymodocea rotundata & + & + & + & + & + \\
\hline & Cymodocea serrulata & + & + & - & - & + \\
\hline & Syringodium isoetifolium & + & + & + & + & + \\
\hline & Thalassodendron ciliatum & - & - & + & + & + \\
\hline \multirow[t]{7}{*}{ Hydrocharitaceae } & Enhalus acoroides & + & + & + & + & + \\
\hline & Halophila beccari & $?$ & $?$ & $?$ & $?$ & $?$ \\
\hline & Halophila decipieae & - & - & - & - & - \\
\hline & Halophila minor & + & + & + & + & + \\
\hline & Halophila ovalis & + & + & + & + & + \\
\hline & Halophila spinulosa & + & + & - & - & + \\
\hline & Thalassia hemprichii & + & + & + & + & + \\
\hline
\end{tabular}

Sumber: den Hartog (1970); Hutomo (1985); Dahuri et al (1996).

Keterangan: (+) ada, ( - ) tidak ada, ( ?) diduga dijumpai tetapi belum tercatat

1= Sumatera; 2=Jawa, Bali, Kalimantan; 3=Sulawesi; 4=Maluku dan Nusa Tenggara; 5=Irian Jaya

Lamun hidup di perairan pesisir dan tersebar di setiap benua di dunia. Lamun umumnya merupakan makanan dugong dan penyu hijau dan menyediakan habitat bagi banyak biota, baik hewan laut kecil seperti udang dan ikan, dan banyak diantaranya merupakan spesies komersial penting. Lamun juga mampu menyerap nutrisi dari limpasan pesisir, menstabilitasi sedimen dan membatu menjawa perairan tetap bersih. Lamun merupakan tanaman khas diantara tumbuhan berbunga lainnya, karena merupakan satu-satunya genus yang mampu hidup di dasar dan kolom perairan laut. Kecuali jenis Enhalus sp yang membutuhkan permukaan perairan laut untuk melakukan reproduksi, seluruh jenis lamun dapat berbuah dan diserbuki di bawah permukaan perairan laut.

Lamun dapat bereproduksi melalui metode seksual dan aseksual. Pada sistem reproduksi seksual, tumbuhan memproduksi bunga dan serbuk dipindahkan dari bunga jantan ke ovarium bunga betina. Kebanyakan spesies lamun memproduksi bunga seks tunggal pada setiap individu, sehingga tumbuhan ini mempunyai dua jenis tumbuhan jantan dan betina yang berbeda. Gambar 1 berikut ini menyajikan ilustrasi komposit yang menunjukkan ciri-ciri utama morfologi lamun dalam rangka membedakan kelompok taksonomi lamun utama.

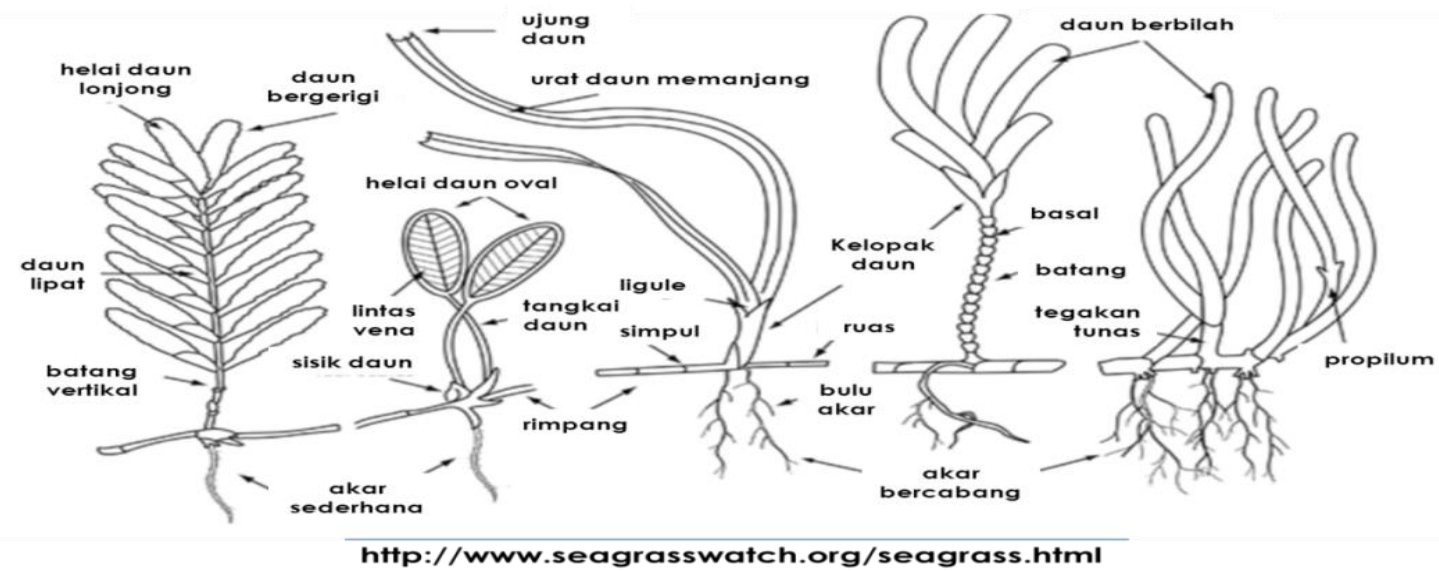

Gambar 1. Ilustrasi komposit yang menunjukkan ciri-ciri morfologi untuk membedakan kelompok taksonomi lamun utama (McKenzie, 2008). 
Tabel 2. Karakteristik kehidupan dan potensi area sebaran lamun

\begin{tabular}{|c|c|c|}
\hline No & Komponen & Keterangan \\
\hline 1 & $\begin{array}{l}\text { Karakteristik } \\
\text { lingkungan perairan }\end{array}$ & $\begin{array}{l}\text { Membutuhkan sinar matahari } \\
\text { Membutuhkan perairan yang bersih } \\
\text { Secara psikologis beradaptasi pada lingkukngan perairan laut } \\
\text { Umumnya bersalinitas } 35 \% \text { dengan toleransi } 4-65 \% \text { (2x konsentrasi } \\
\text { perairan laut, untuk jenis tertentu) } \\
\text { Kebutuhan cahaya } 4,4-29 \% \\
\text { Suhu perairan dalam toleransi antara } 38-42{ }^{\circ} \mathrm{C}\end{array}$ \\
\hline 2 & Sifat hidup & $\begin{array}{l}\text { Membutuhkan pernafasan untuk mendukung perkembangan biomassa } \\
\text { melalui proses fotosintesis (seperti akar dan rimpang) } \\
\text { Kurang memiliki pigmen tertentu dan karenanya hanya dapat memanfaatkan } \\
\text { spektrum yang terbatas } \\
\text { Mengalami stress pada temparatur perairan yang yang melebihi } 40^{\circ} \mathrm{C} \text {, } \\
\text { bahkan jika lebih dari } 45^{\circ} \mathrm{C} \text { dapat mengalami kematian } \\
\text { Membutuhkan masukan organik karbon untuk pertumbuhannya } \\
\text { Membutuhkan nutrisi kunci untuk tumbuh, yaitu nitrogen (N) dan fosfor (P) } \\
\text { Membutuhkan pasang surut untuk proses penyerbukan dan pergantian gas } \\
\text { dari air ke dalam tanaman lamun } \\
\text { Tumbuh dari mulai anakan kecil hingga menjadi padang lamun yang besar } \\
\text { dan luas }\end{array}$ \\
\hline 3 & $\begin{array}{l}\text { Karakteristik area } \\
\text { penyebaran lamun }\end{array}$ & $\begin{array}{l}\text { Lokasi perairan pesisir yang dangkal dan di atas karang } \\
\text { Perairan pantai yang dangkal diantara permukaan laut rata-rata dan } \\
\text { kedalaman } 25 \text { meter } \\
\text { Daerah perairan pasang-surut yang terhampar pada substrat lembut seperti } \\
\text { pasir dan lumpur } \\
\text { Kedalaman air yang sangat tergantung dari ketersediaan cahaya matahari } \\
\text { (kecerahan perairan) }\end{array}$ \\
\hline
\end{tabular}

Lamun memerlukan cahaya, nutrisi, karbon dioksida $\left(\mathrm{CO}_{2}\right)$, substrat sebagai media tumbuh, serta salinitas, suhu dan $\mathrm{pH}$ yang cukup untuk dapat tumbuh dan berkembang (McKenzie, 2008). Lamun dapat eksis di lingkungan perairan laut dan mampu beradaptasi untuk hidup dalam perairan asin sedang. Lamun dapat tumbuh bilamana benar-benar tenggelam. Sistem perakaran lamun mampu menahan kekuatan gelombang dan sebagai penahan arus pasang surut. Penyerbukan lamun dilakukan dengan bantuan air laut. Tabel 2 berikut ini menyajikan beberapa karakterisrik kehidupan dan potensi area sebaran yang memungkinkan untuk lamun dapat tumbuh dan berkembang dengan baik.

Lamun merupakan sumberdaya alam penting yang memberikan banyak fungsi yang berharga (Fortes, 1991; Fish and Wildlife Research Institute, 1999; McKenzie, 2008; Hughes et al, 2009; Cullen-Unsworth et al, 2014). Tabel 3 berikut ini menyajikan beberapa fungsi ekosistem lamun yang bermanfaat bagi kehidupan dan penghidupan masyarakat di wilayah pesisir dan pulau-pulau kecil. 
Tabel 3. Fungsi dan peranan ekosistem lamun yang bermanfaat bagi masyarakat pesisir dan pulau-pulau kecil

\begin{tabular}{|c|c|c|}
\hline No & Jenis Fungsi Lamun & Keterangan \\
\hline 1 & Fisik & $\begin{array}{l}\text { Lamun dapat menstabilkan dasar laut dengan akar-akarnya dan rimpang } \\
\text { dalam banyak cara yang sama bahwa rumput tanah menghambat erosi } \\
\text { tanah (kepentingan fungsinya seringkali terlihat jelas ketika badai } \\
\text { mendekati garis pantai dan mengancam pantai, bisnis, dan rumah) } \\
\text { Lamun dapat membantu menjaga kejernihan air dengan menjebak } \\
\text { sedimen halus dan partikel. Daerah bawah (substrat) tanpa lamun lebih } \\
\text { sering diaduk oleh angin dan ombak sehingga dapat mengurangi } \\
\text { kejernihan air dan mempengaruhi perilaku biota laut dan kualitas rekreasi } \\
\text { wilayah pesisir } \\
\text { Lamun membuat aliran air menjadi lebih lambat dan menyebabkan } \\
\text { sedimen tetap di dasar perairan sehingga membantu perairan tetap jernih. }\end{array}$ \\
\hline 2 & Kimia & $\begin{array}{l}\text { Memelihara kualitas perairan, termasuk hadirnya kandungan oksigen dan } \\
\text { unsur hara yang dibutuhkan makhluk hidup yang berasosiasi dengan } \\
\text { lamun. } \\
\text { Lamun juga berkontribusi terhadap produktivitas ekosistem melalui jalur } \\
\text { makanan detritus. } \\
\text { Lamun membantu menghilangkan (menyerap) nutrisi yang membahayakan } \\
\text { dan polusi sedimen dari perairan pesisir. }\end{array}$ \\
\hline 3 & Biologi & $\begin{array}{l}\text { Lamun menyediakan habitat bagi berbagai jenis ikan, udang-udangan, dan } \\
\text { kerang. Penelitian telah menunjukkan banyak spesies laut tergantung pada } \\
\text { keberadaan lamun sebagai habitat hidupnya } \\
\text { Lamun dan organisme yang tumbuh dan berasosiasi dengannya adalah } \\
\text { sumber makanan bagi banyak biota, termasuk mamalia laut seperti } \\
\text { dugong. Pada permukaan daun lamun, hidup melimpah ganggang- } \\
\text { ganggang renik (biasanya ganggang bersel tunggal), hewan-hewan renik } \\
\text { dan mikroba yang merupakan makanan bagi bermacam jenis ikan yang } \\
\text { hidup di sekitar padang lamun. } \\
\text { Komunitas lamun merupakan habitat penting dan daerah sumber makanan } \\
\text { bagi organisme laut yang ada di sekitarnya. Sekitar } 40 \text { kali lebih banyak } \\
\text { jumlah biota laut daripada padang pasir, yang menjadikan lamun sebagai } \\
\text { daerah asuhan (nursery ground), tempat mencari makan (feeding ground) } \\
\text { dan tempat berkembang biak (spawning ground) } \\
\text { Lamun merupakan makanan bagi dugong (Dugong dugon) dan penyu hijau } \\
\text { (Chelonia mydas). Dugong dapat menghabiskan sebanyak } 28-40 \mathrm{~kg} \\
\text { lamun per hari sebagai nutrisi pertumbuhannya. Dugong dan penyu hijau } \\
\text { memilah jenis-jenis lamun yang memiliki tingkat nitrogen tinggi, kandungan } \\
\text { nutrisi tinggi dan memiliki serat rendah. }\end{array}$ \\
\hline 4 & Sosial Ekonomi & $\begin{array}{l}\text { Menyediakan bahan makanan, seperti buah lamun, misalnya samo-samo } \\
\text { (Enhalus acoroides) oleh penduduk di beberapa pulau kecil di Indonesia } \\
\text { telah dimanfaatkan bijinya sebagai bahan makanan. } \\
\text { Mendukung pengembangan ekonomi lokal, melalui kegiatan perikanan dan } \\
\text { wisata }\end{array}$ \\
\hline
\end{tabular}

Sumber: Disarikan dari Nontji (1987); Hutomo et al (1988); Heck and Weistein (1989); Fortes (1991); Hutomo dan Azkab (1993); Nienhuis (1993); Peristiwady (1993). Koesoebiono (1995); Dahuri et al (1996); Fish and Wildlife Research Institute (1999); McKenzie (2008); Hughes et al (2009); CullenUnsworth et al (2014) 


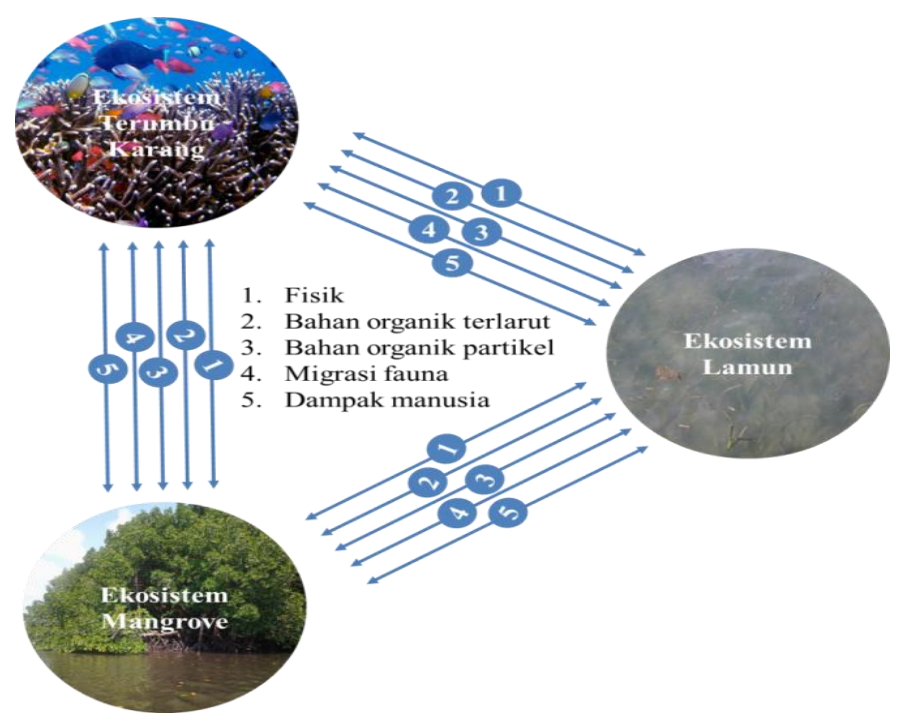

Gambar 2. Interaksi terumbu karang, lamun dan mangrove (McKenzie, 2008)

Ekosistem pesisir dan laut seperti terumbu karang, mangrove dan lamun mempunyai keterikatan kuat dan saling mendukung satu sama lainnya. Terumbu karang, lamun dan mangrove saling berinteraksi dan saling menyediakan dukungan fisik dan biologis kepada masingmasing ekosistem.

Gambar menunjukkan hubungan antara terumbu karang, lamun dan mangrove dengan saling menyediakan dukungan fisik dan biologis kepada masing-masing ekosistem (McKenzie, 2008).

Lamun merupakan salah satu ekosistem penting di perairan pesisir Indonesia yang telah mengalami penurunan kualitas dan kuantitas akibat banyaknya aktivitas beberapa sektor terkait dengan kegiatan manusia, seperti ekologi, sosialekonomi, teknologi dan kelembagaan. Penurunan dan kerugian padang lamun akan sangat berdampak terhadap bukan hanya keanekaragaman hayati dan produktivitas perikanan yang berasosiasi dengan ekosistem ini, melainkan juga terhadap ekosistem lainnya seperti terumbu karang dan mangrove, atau bahkan lebih jauh lagi pada ekosistem laut yang masih dipengaruhi oleh ekosistem pesisir (Nadiarti et al, 2012).

Berdasarkan peraturan perundangundangan di Indonesia lamun didefinisikan sebagai salah satu sumberdaya pesisir dan pulau-pulau kecil sesuai dengan Pasal 1 butir
(4) Undang-Undang Nomor 27 Tahun 2007 tentang Pengelolaan Wilayah Pesisir dan Pulau-Pulau Kecil. Ekosistem lamun merupakan satu dari tiga ekosistem utama yang ada di wilayah pesisir yang dapat dimanfaatkan untuk berbagai kepentingan, diantaranya: (i) konservasi, (ii) pendidikan dan pelatihan, (iii) penelitian dan pengembangan, (iv) budidaya laut, (v) pariwisata, (vi) usaha perikanan dan kelautan dan industri perikanan secara lestari, (vii) pertanian organik dan/atau (viii) peternakan. Oleh karena itu, tidaklah mengherankan bilamana ekosistem lamun perlu mendapatkan perhatian pengelolaan, dengan salah satunya dijadikan sebagai kawasan konservasi ekosistem lamun. Konservasi ekosistem lamun sebagai salah satu sumberdaya wilayah pesisir dapat diselenggarakan dengan tujuan: (i) menjaga kelestarian ekosistem lamun, (ii) melindungi alur migrasi ikan dan biota laut lain yang berasosiasi dengan ekosistem lamun, (iii) melindungi ekosistem lamun sebagai habitat biota laut, dan (iv) melindungi situs budaya/ warisan sumberdaya lokal (Mahifal, 2010).

\section{Jasa-jasa ekosistem lamun}

Ekosistem menurut definisi dari Kamus Biologi Online didefnisikan sebagai sebuah sistem yang mencakup semua organisme hidup (faktor biotik) di suatu wilayah serta lingkungan fisik (faktor abiotik) yang berfungsi bersama-sama sebagai satu kesatuan unit. Suatu ekosistem dapat terdiri dari tumbuhan, 
hewan, mikroorganisme, tanah, batuan, mineral, sumber air dan suasana lokal berinteraksi dengan satu sama lain. Sehingga tidaklah mengherankan bilamana kemudian jasa ekosistem didefinisikan sebagai semua manfaat yang berguna bagi manusia yang dapat diperoleh dari suatu ekosistem (Eliezer, 2001). Definisi jasa ekosistem berkembang dan semakin meluas untuk menggambarkan bagaimana suatu ekosistem memberikan layanan yang sangat bermanfaat bagi pemenuhan kebutuhan dan kesejahteraan umat manusia baik secara langsung maupun tidak langsung. Tabel 4 berikut ini menyajikan beberapa definisi jasa ekosistem yang umum digunakan sebagai definisi ilmiah oleh para peneliti dan lembaga terkait di dunia.

Tabel 4. Berbagai definisi jasa ekosistem yang umum digunakan para peneliti dan lembaga terkait di dunia

\begin{tabular}{|c|c|c|}
\hline No & Definisi & Referensi \\
\hline 1 & $\begin{array}{l}\text { Jasa ekosistem sebagai manfaat yang diperoleh manusia dari ekosistem, } \\
\text { termasuk didalamnya penyediaan layanan seperti makanan dan air, jasa } \\
\text { pengaturan banjir dan pengendalian penyakit, layanan budaya seperti } \\
\text { spiritual, rekreasi, dan manfaat budaya, dan jasa penunjang seperti siklus } \\
\text { hara, yang menjaga kondisi lahan untuk kehidupan di bumi. }\end{array}$ & $\begin{array}{l}\text { United Nations } \\
\text { Environment } \\
\text { Programme (1993) }\end{array}$ \\
\hline 2 & $\begin{array}{l}\text { Jasa ekosistem adalah layanan dari sistem ekologi dan stok modal alam } \\
\text { yang menghasilkan barang dan jasa yang sangat penting untuk fungsi } \\
\text { sistem pendukung kehidupan bumi. }\end{array}$ & $\begin{array}{l}\text { Costanza et al } \\
\text { (1997); de Groot et all } \\
(2000)\end{array}$ \\
\hline 3 & $\begin{array}{l}\text { Jasa ekosistem didefinisikan sebagai manfaat penting bagi manusia yang } \\
\text { muncul dari ekosistem dan berfungsi menopang kehidupan dan } \\
\text { penghidupan manusia. Jasa ekosistem sebagai manfaat yang diperoleh }\end{array}$ & $\begin{array}{l}\text { Dictionary (1995) } \\
\text { Wikimedia } \\
\text { Foundation (2001) }\end{array}$ \\
\hline & $\begin{array}{l}\text { manusia dari ekosistem. Manfaat ini diantaranya termasuk (i) layanan } \\
\text { penyediaan, seperti penyedia makanan dan air, (ii) layanan pengaturan } \\
\text { seperti mengatur banjir dan pengendalian penyakit, (iii) layanan budaya } \\
\text { seperti manfaat spiritual, rekreasi, dan budaya, serta (iv) layanan } \\
\text { pendukung, seperti siklus nutrisi yang menjaga kondisi untuk kehidupan di } \\
\text { Bumi. }\end{array}$ & $\begin{array}{l}\text { The Free Dictionary } \\
\text { by Farlex (2003); } \\
\text { Greenfacts (Selliers, } \\
\text { 2001) }\end{array}$ \\
\hline 4 & $\begin{array}{l}\text { Jasa ekosistem sebagai manfaat yang dapat diperoleh manusia dari suatu } \\
\text { ekosistem, termasuk diantaranya manfaat air, makanan, bahan baku, } \\
\text { stabilisasi tepi pantai, perlindungan dari banjir dan badai, pengaturan aliran } \\
\text { air, kualitas air, pengendali penyakit manusia, pengolahan limbah, stok } \\
\text { karbon, regulasi dan siklus nutrien, habitat, produksi primer, pendidikan } \\
\text { dan ilmu pengetahuan, wisata, estetika dan rekreasi. }\end{array}$ & $\begin{array}{l}\text { Earth Economics } \\
\text { (Batker, 2003) }\end{array}$ \\
\hline 5 & $\begin{array}{l}\text { Jasa ekosistem adalah sebagai manfaat bagi manusia yang berasal dari } \\
\text { ekosistem. Selain jasa atau barang seperti makanan, kayu dan bahan baku } \\
\text { lainnya pengadaan, tanaman, hewan, jamur dan mikro-organisme, jasa } \\
\text { ekosistem juga menyediakan layanan penting lainnya, seperti mengatur } \\
\text { penyerbukan tanaman, pencegahan erosi tanah dan pemurnian air, dan } \\
\text { area yang luas untuk layanan budaya, seperti rekreasi dan kecintaan pada } \\
\text { suatu tempat. Terlepas dari kepentingan ekologi, budaya dan ekonomi dari } \\
\text { layanan ini, ekosistem dan keanekaragaman hayati yang mendukung } \\
\text { mereka masih terdegradasi dan mengalami kepunahan pada skala belum } \\
\text { pernah terjadi sebelumnya. }\end{array}$ & $\begin{array}{l}\text { Millenium Ecosystem } \\
\text { Assessment (2003) }\end{array}$ \\
\hline 6 & $\begin{array}{l}\text { Jasa ekosistem didefinisikan sebagai berbagai kategori layanan ekosistem } \\
\text { yang menyediakan manfaat bagi manusia. TEEB membagi jasa ekosistem } \\
\text { menjadi } 4 \text { (empat) layanan ekosistem, diantaranya yaitu: (i) layanan } \\
\text { penyediaan, (ii) layanan pengaturan, (iii) layanan habitat atau jasa } \\
\text { pendukung, dan (iv) layanan budaya. Layanan penyediaan adalah jasa } \\
\text { ekosistem yang menggambarkan materi atau output energi yang dihasilkan } \\
\text { dari ekosistem (produksi). }\end{array}$ & $\begin{array}{l}\text { The Economic of } \\
\text { Ecosystem and } \\
\text { Biodiversity (TEEB) } \\
\text { (UNEP, 2008) }\end{array}$ \\
\hline
\end{tabular}

Sumber: disarikan dari berbagai referensi. 
Tabel 5. Kategori jasa dan jenis produk jasa ekosistem lamun untuk kesejahteraan manusia menurut Millennium Ecosystem Assessment (2005)

\begin{tabular}{|c|c|c|c|}
\hline No & Kategori Jasa & Jenis Produk & $\begin{array}{c}\text { Disediakan } \\
\text { Ekosistem Lamun }\end{array}$ \\
\hline \multirow[t]{7}{*}{1} & Jasa Pengaturan & Makanan & $\mathrm{x}$ \\
\hline & & Bahan & - \\
\hline & & Bahan bakar & t.a.d \\
\hline & & Sumberdaya genetik & $\mathrm{x}$ \\
\hline & & Sumber biokimia & $\mathrm{X}$ \\
\hline & & Sumberdaya hiasan & $\mathrm{x}$ \\
\hline & & Air tawar & - \\
\hline \multirow[t]{9}{*}{2} & Jasa Penyediaan/ & Peraturan kualitas udara & t.a.d \\
\hline & Produksi & Pengaturan iklim & t.a.d \\
\hline & & Pengaturan air & t.a.d \\
\hline & & Pengaturan erosi & $\mathrm{x}$ \\
\hline & & Pemurnian air dan pengolahan limbah & $\mathrm{X}$ \\
\hline & & Pengaturan penyakit & t.a.d \\
\hline & & Regulasi hama & t.a.d \\
\hline & & Penyerbukan & $\mathrm{x}$ \\
\hline & & Peraturan bahaya alam & $\mathrm{X}$ \\
\hline \multirow[t]{10}{*}{3} & Jasa Budaya/ & Keragaman budaya & t.a.d \\
\hline & Informasi & Nilai-nilai spiritual dan keagamaan & t.a.d \\
\hline & & Sistem pengetahuan (tradisional dan formal) & $\mathrm{x}$ \\
\hline & & Nilai-nilai pendidikan & $\mathrm{X}$ \\
\hline & & Inspirasi & $\mathrm{x}$ \\
\hline & & Nilai-nilai estetika & $\mathrm{x}$ \\
\hline & & Hubungan sosial & t.a.d \\
\hline & & Kecintaan akan suatu tempat & t.a.d \\
\hline & & Nilai-nilai warisan budaya & t.a.d \\
\hline & & Rekreasi dan ekowisata & $\mathrm{x}$ \\
\hline \multirow[t]{5}{*}{4} & Jasa Pendukung/ & Pembentukan tanah & \\
\hline & Habitat & Fotosintesis & $\mathrm{x}$ \\
\hline & & Produksi primer & $\mathrm{X}$ \\
\hline & & Siklus hara & $x$ \\
\hline & & Siklus air & t.a.d \\
\hline
\end{tabular}

Sumber: Tabel 3.

Keterangan: $(X)=$ disediakan dan merupakan jasa ekosistem lamun; (-) tidak disediakan; (t.a.d) tidak ada referensi

Berdasarkan berbagai referensi definisi tersebut, maka dapat disimpulkan bahwa jasa ekosistem adalah berbagai manfaat yang dapat diperoleh manusia sebagai sumber kehidupan dan penghidupan, baik secara langsung maupun tidak langsung, atas keberadaan suatu ekosistem. Disepakati juga 4 (empat) kategori jasa ekosistem yang digunakan, yaitu (i) jasa pengaturan, (ii) jasa penyediaan/produksi, (iii) jasa budaya/seni, dan (iv) jasa pendukung/habitat. Oleh karena itu, dengan referensi tersebut, maka kategori jasa ekosistem lamun yang menyediakan manfaat bagi kesejahteraan manusia selengkapnya dapat dlihat pada Tabel 5.

\section{Nilai ekonomi jasa ekosistem lamun}

Jasa ekosistem berkontribusi terhadap kesejahteraan manusia, baik secara langsung maupun tidak langsung, dan karena itu merupakan bagian dari nilai ekonomi total bumi (Costanza et al, 1997). Costanza et (1997) telah melakukan estimasi terhadap seberapa besar kekayaan bumi berdasarkan 17 jasa ekosistem untuk 16 bioma yang dilakukan berdasarkan berbagai referensi hasil penelitian yang telah dipublikasikan maupun dari beberapa perhitungan asli yang dilakukan sendiri. Hasil estimasi menunjukkan bahwa untuk keseluruhan nilai biosfer (nilai yang sebagian besar berada di luar pasar) diperkirakan berada di kisaran US \$16-54 trilyun per tahun, dengan rata-rata US 
\$33 trilyun per tahun. Karena sifat ketidakpastian, maka nilai ini harus dianggap sebagai estimasi minimum.

Costanza et al (1997) menyebutkan bahwa mayoritas nilai jasa ekosistem diidentifikasi dengan menggunakan pendekatan non pasar. Jasa pengaturan gas diperkirakan mencapai sebesar US \$1.3 trilyun per tahun, jasa pengaturan gangguan/tekanan mencapai US \$1.8 trilyun per tahun, jasa pengolahan limbah mencapai US \$ 2.3 trilyun per tahun dan jasa siklus nutrisi mencapai sebesar US \$ 1.7 trilyun per tahun. 63\% dari nilai estimasi disumbangkan oleh sistem laut dan pesisir, dimana sistem laut menyumbang nilai ekonomi sebesar US \$ 20.9 trilyun per tahun dan sistem pesisir menyumbang sebesar US \$ 10.6 trilyun per tahun. Adapun sisanya sebesar $38 \%$ berasal dari nilai taksiran dari sistem terestrial, terutama dari hutan, yaitu mencapai sebesar US \$ 4.7 trilyun per tahun dan lahan basah mencapai sebesar US $\$ 4.9$ trilyun per tahun.

Setelah lebih dari satu dasawarsa, Costanza et al (2014) kembali melakukan estimasi terhadap kekayaan biosfer dan hasilnya menunjukkan bahwa nilai total kekayaan bumi adalah sebesar US \$ 145 trilyun per tahun dengan asumsi tidak ada perubahan luas dari masing-masing bioma yang ada di muka bumi. Namun demikian, berdasarkan data global yang dimilikinya, telah terjadi perubahan luas bioma, sehingga nilai total kekayaan bumi yang riil saat ini hanya sebesar US $\$ 124,8$ trilyun per tahun. Bilamana mangrove dihitung sebagai bagian dari sistem laut, maka kontribusi sistem ini terhadap kekayaan bumi mencapai sebesar 63,78 persen, sedangkan bilamana mangrove dimasukkan ke dalam sistem teresterial, maka kontribusi sistem laut hanya sebesar 41,72 persen dari keseluruhan nilai bumi.

Ekosistem lamun sendiri diperkirakan mengalami peningkatan nilai dari tahun 1997 sebesar US \$26.226 per hektar per tahun menjadi sebesar US \$28.916 per hektar per tahun pada tahun 2014 (Costanza et al, 1997; Costanza et al, 2014). Peningkatan nilai ini dapat diakibatkan oleh semakin banyaknya penelitian yang terkait dengan ekosistem ini dan memberikan bukti bahwa ekosistem lamun memberikan banyak manfaat ekonomi bagi kesejahteraan masyarakat. Tabel 6 berikut ini menyajikan hasil interasi terhadap beberapa referensi terkait dengan nilai ekonomi ekosistem lamun.

Tabel 6. Nilai ekonomi ekosistem lamun dari berbagai referensi

\begin{tabular}{|c|c|c|c|c|c|}
\hline \multirow{2}{*}{ No } & \multirow{2}{*}{$\begin{array}{c}\text { Jasa Ekosistem } \\
\text { Lamun }\end{array}$} & \multicolumn{2}{|c|}{ Nilai Ekonomi } & \multirow{2}{*}{ Referensi } & \multirow{2}{*}{$\begin{array}{c}\text { Estimasi Nilai Tahun } \\
2016 \\
\text { (Rp.juta/ha/tahun) }\end{array}$} \\
\hline & & Satuan & Nilai & & \\
\hline 1 & $\begin{array}{l}\text { Seluruh jasa } \\
\text { ekosistem }\end{array}$ & US\$/ha/tahun & $26.226,00$ & $\begin{array}{l}\text { Costanza et al } \\
\text { (1997) }\end{array}$ & 354,05 \\
\hline 2 & $\begin{array}{l}\text { Produksi dan } \\
\text { habitat }\end{array}$ & Rp. juta/ha/tahun & 472,63 & $\begin{array}{l}\text { PKSPL IPB } \\
\text { (1999) }\end{array}$ & $1.105,78$ \\
\hline 3 & Habitat ikan & AU\$/ha/tahun & 18,50 & $\begin{array}{l}\text { McArthur \& } \\
\text { Boland (2006) }\end{array}$ & 0,34 \\
\hline 4 & $\begin{array}{l}\text { Produksi ikan, } \\
\text { biota \& budaya }\end{array}$ & Rp. juta/ha/tahun & $1.062,97$ & $\begin{array}{l}\text { Al Hadad } \\
\text { (2011) }\end{array}$ & $1.298,31$ \\
\hline 5 & Produksi ikan & Rp. juta/ha/tahun & 16,26 & $\begin{array}{l}\text { PKSPL IPB } \\
\text { (2012) }\end{array}$ & 19,86 \\
\hline 6 & $\begin{array}{l}\text { Produksi ikan } \\
\text { dan biota }\end{array}$ & Rp. juta/ha/tahun & 254,72 & $\begin{array}{l}\text { Adrianto et al } \\
\text { (2013) }\end{array}$ & 295,94 \\
\hline 7 & $\begin{array}{l}\text { Seluruh jasa } \\
\text { ekosistem }\end{array}$ & US\$/ha/tahun & $28.916,00$ & $\begin{array}{l}\text { Costanza et al } \\
(2014)\end{array}$ & 390,37 \\
\hline \multicolumn{5}{|c|}{ Nilai ekonomi rata-rata geometrik ekosistem lamun } & 121,75 \\
\hline
\end{tabular}

Sumber: Diolah dari berbagai sumber. 
Berdasarkan ketersediaan referensi yang diperoleh, maka nilai ekonomi ekosistem lamun dapat diestimasi diantara Rp. 0,34 1298,31 juta per hektar per tahun atau bilamana dirata-ratakan secara geometrik mencapai sebesar Rp. 121,75 juta per hektar per tahun. Tentu saja sesuai dengan yang disampaikan oleh Costanza et al (1997; 2014), seiring dengan perkembangan dan kemampuan analisis terhadap setiap komponen jasa ekosistem yang dimiliki oleh suatu ekosistem, maka nilai ekonomi ekosistem lamun sebesar Rp.121,75 juta per hektar per tahun ini dapat ditetapkan sebagai nilai minimal dari keberadaan ekosistem tersebut.

\section{Kebijakan pengelolaan lamun}

Keberadaan fungsi dan manfaat keberadaan ekosistem lamun telah memberikan gambaran akan pentingnya kehadiran lamun sebagai sebuah ekosistem yang berguna dan diperlukan oleh masyarakat pesisir dan laut. Beragam manfaat barang dan jasa yang mampu disediakan ekosistem lamun secara langsung dan tidak langsung dapat memenuhi kebutuhan dan kesejahteraan manusia. Besaran manfaat minimum ekonomi dari kehadiran ekosistem lamun bagi manusia telah dapat diestimasi sebesar Rp.121,75 juta per hektar per tahun. Tentu saja, semua bukti manfaat dan nilai jasa tersebut seyogianya dapat menjadi dasar bahwa pengelolaan ekosistem lamun yang dilakukan secara berkelanjutan dan berbasis masyarakat lokal sangat diperlukan dalam rangka menjaga keberlanjutan manfaat kehadiran ekosistem lamun tersebut di masa mendatang.

Kehadiran ekosistem lamun tentu saja akan terasa lebih signifikan bilamana kehadiran ekosistem pesisir terkait lainnya (mangrove dan terumbu karang) juga terpelihara. Selain itu, kehadiran ekosistem lamun sangat dipengaruhi oleh beberapa aktivitas di wilayah pesisir dan pulau-pulau kecil yang melibatkan berbagai sektor ekonomi dan jasa kelautan. Oleh karena itu, maka pengelolaan ekosistem lamun haruslah mampu disinergikan dengan pengelolaan pesisir terpadu sebagai payung pengelolaan terpadu, sehingga tujuan pengelolaan ekosistem pesisir dan laut, termasuk ekosistem lamun di dalamnya dapat dilakukan secara terpadu dan berkelanjutan.

Menurut Charles (2012) sangat penting bagi manusia untuk dapat mempunyai sistem berpikir bahwa ekosistem pada tingkat lokal merupakan bagian dari sistem global, dimana satu dengan yang lainnya saling berkaitan dan saling memberikan dampak. Hal ini diperlukan agar pemahaman sempit terhadap manfaat suatu ekosistem dapat dieliminir sehingga sistem pengelolaan yang akan diterapkan tidak mengindahkan prinsip-prinsip keberlanjutan ekosistem global secara keseluruhan. Gambar 3 berikut ini menyajikan gambaran bagaimana sistem lokal berpengaruh terhadap sistem global dan demikian pula sebaliknya.

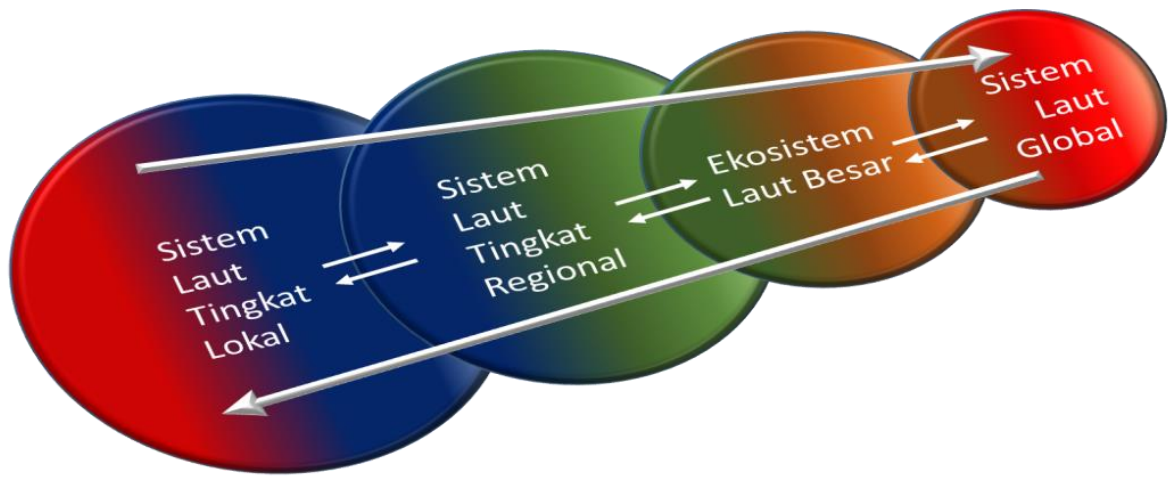

Gambar 3. Kerangka interaksi saling berpengaruh antar sistem sumberdaya dari mulai tingkat lokal, regional dan global (diadopsi dari Charles, 2012). 
Dalam konteks pengelolaan sumberdaya pesisir dan laut, Adrianto et al (2013; 2015) menyatakan bahwa sangat penting bagi para pemangku kepentingan (baik pengguna maupun pembuat kebjakan) untuk memahami kebijakan pengelolaan terpadu dan menyeluruh yang berbasis pada pendekatan sistem mikro yang disinkronisasi dengan kepentingan sistem makro yang lebih kompleks. Oleh karena itu, desain kebijakan dan pendekatan pengelolaan ekosistem lamun inipun haruslah juga mengacu kepada kerangka pengelolaan sumberdaya pesisir secara terpadu dan menyeluruh. Gambar 4 berikut ini menunjukkan bagaimana pola interaksi sistem mikro (ekosistem lamun) dengan sistem makro (keseluruhan ekosistem dan ragam aktivitas terkait) serta hubungannya dengan pengelolaan sumberdaya pesisir terpadu (Adrianto et al, 2013).

Gambar 4 menunjukkan bahwa ekosistem lamun sangat terkait dengan keberadaan ekosistem pesisir dan laut lainnya (mangrove, terumbu karang dan oseanik/pelagik), dimana kehadiran ekosistem lamun mampu memberikan aliran barang dan jasa yang dibutuhkan oleh makhluk hidup termasuk manusia, sehingga diperlukan kebijakan yang baik dan terpadu agar keberadaan aliran barang dan jasa tersebut dapat tetap terjaga keberlanjutannya, yang salah satunya adalah dengan adanya kebijakan perlindungan dan rehabilitasi ekosistem pesisir dan laut, termasuk didalamnya ekosistem lamun. Oleh karena itu, kebijakan pengelolaan ekosistem lamun harus dibungkus dan terintegrasi dengan kebijakan pengelolaan sumberdaya pesisir secara terpadu dan menyeluruh.

Mengingat kompleksitas interaksi antara manusia dan alam dalam pengelolaan sumberdaya perikanan lamun, maka permasalahan-permasalahan yang melekat di dalamnya sangatlah bersifat path dependence, dimana penyelesaian permasalahannya akan sangat tergantung pada bagaimana mengambil pelajaran terhadap kegagalan-kegagalan pengelolaan pada masa lalu (Fauzi, 2005). Pengelolaan yang berbeda perlu dilakukan untuk menangani ketidakpastian dalam informasi dan pengendalian hasil dalam pengelolaan ekosistem, dimana pengelolaan didasari atas tingkat ketidakpastian dan tingkat pengendalian. Tingkat ketidakpastian beranjak mulai dari rendah hingga tingg, sedangkan tingkat pengendalian beranjak dari mulai yang dapat dikendalikan hingga yang tidak dapat dikendalikan (Peterson et al, 2003). Oleh karena itu, desain kebijakan seyogianya dapat didesain secara kombinasi dan terintegrasi dengan mengedepankan prinsip-prinsip keberlanjutan (ekologi), efisiensi (ekonomi), dan distribusi (sosial). Tabel 7 berikut ini menyajikan desain kebijakan pengelolaan ekosistem lamun dengan memperhatikan beberapa kemungkinan tujuan ekologi, ekonomi dan sosial.

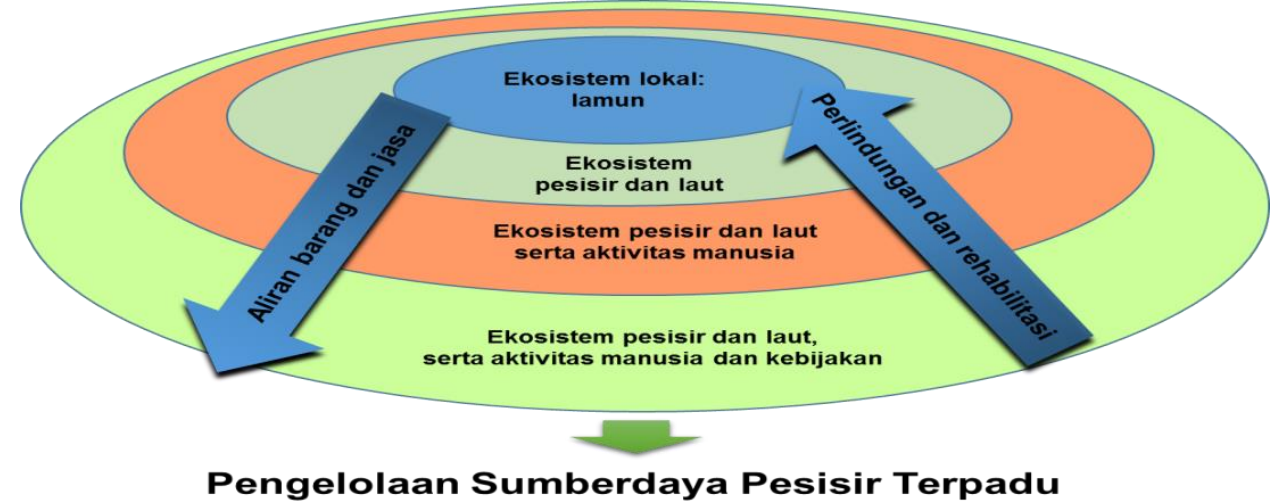

Gambar 4. Interaksi sistem lamun (mikro) dan sistem wilayah pesisir dan laut beserta seluruh aktivitas dan kebijakannya (makro) dan hubungannya dengan pengelolaan sumberdaya pesisir terpadu (Adrianto et al, 2013). 
Tabel 7. Desain kebijakan pengelolaan ekosistem lamun

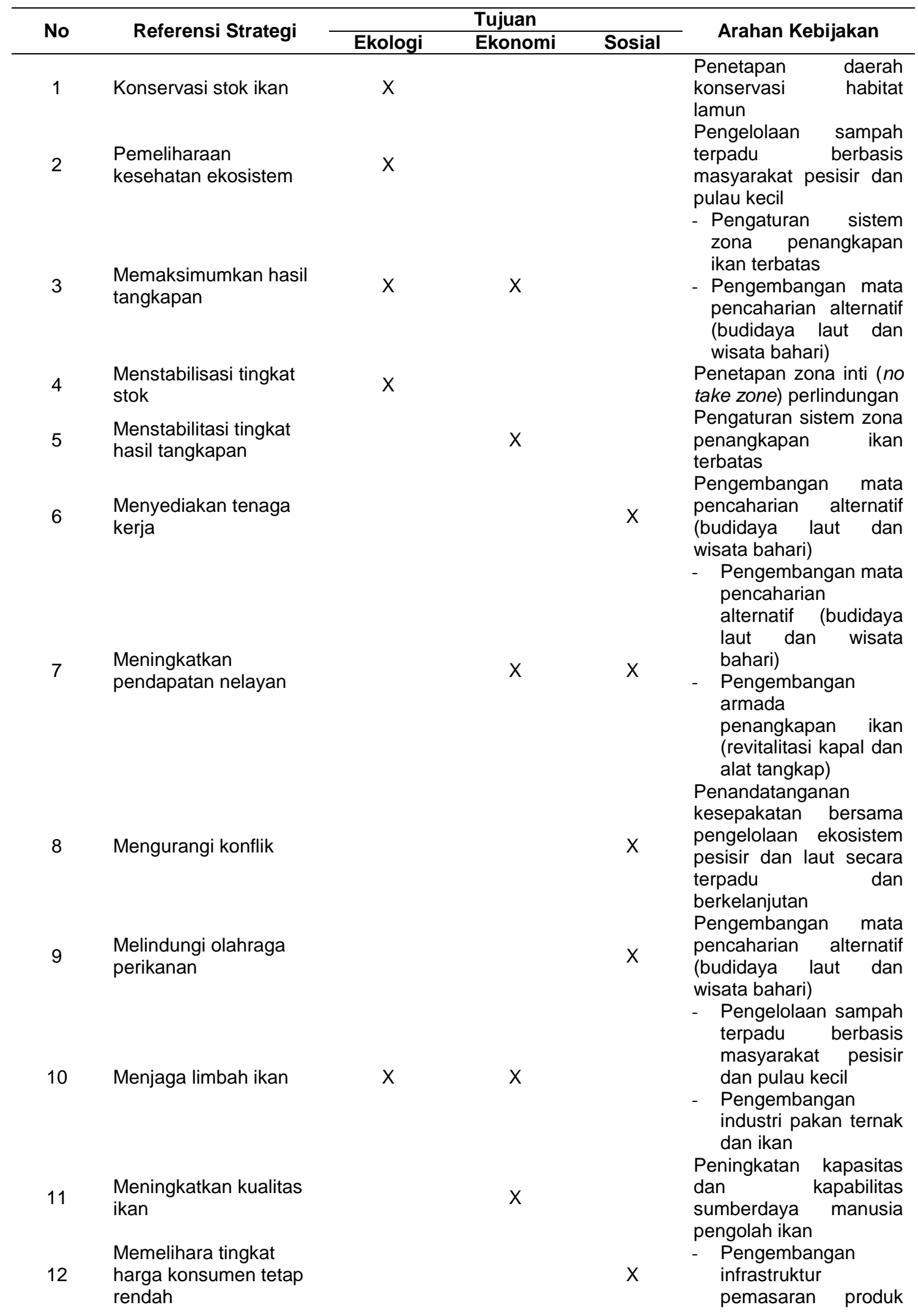




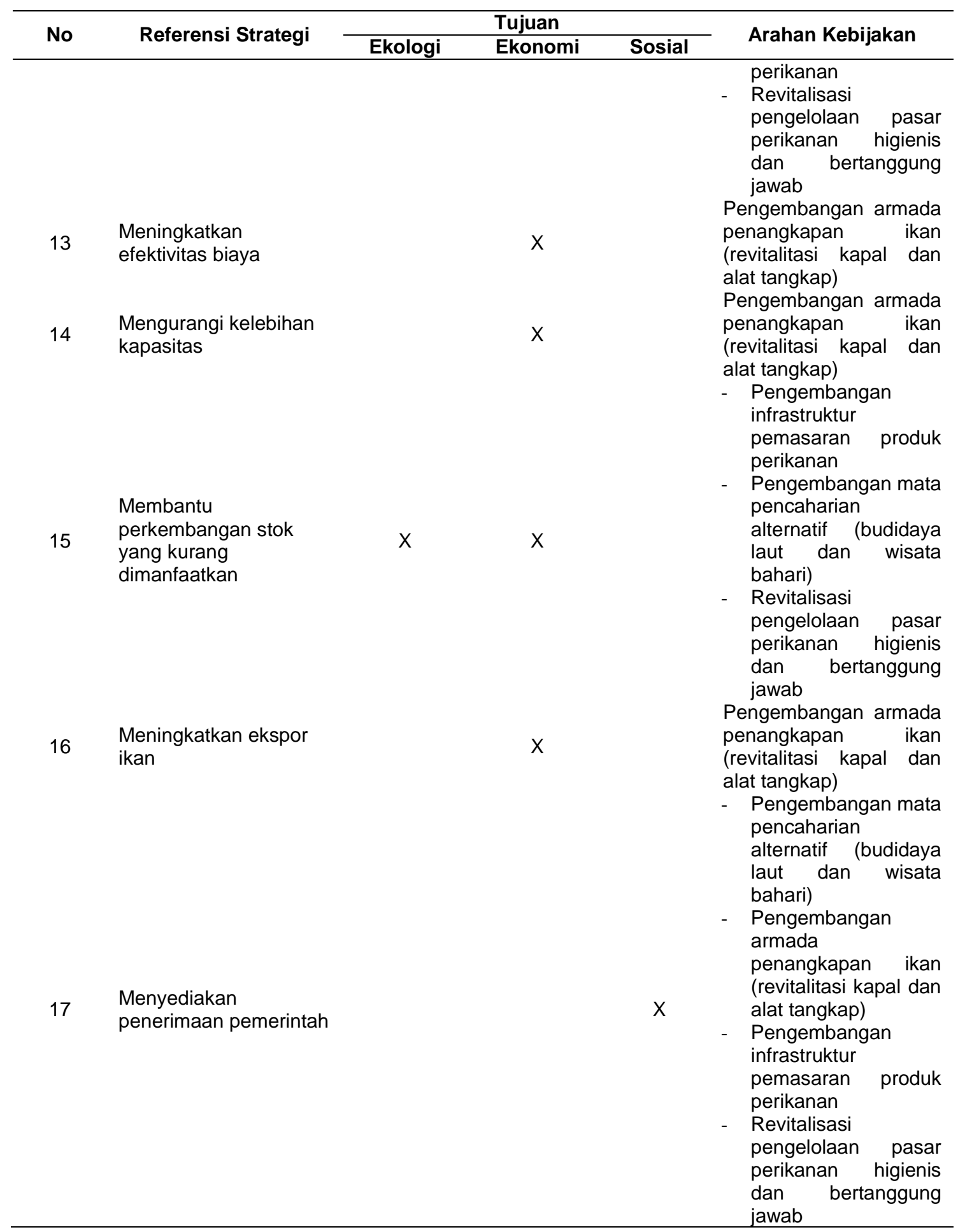

Sumber: Clark (1985); Charles (2012); Adrianto et al (2013); Adrianto et al (2015). 


\section{Penutup}

Ekosistem lamun memberikan manfaat yang tidak sedikit bagi kesejahteraan masyarakat, berupa jasa ekosistem yang sangat bernilai dan dibutuhkan oleh manusia, baik secara ekologi, sosial, maupun secara ekonomi. Jasa penyediaan, jasa pengaturan, jasa budaya/informasi dan jasa pendukung/habitat disediakan secara lengkap oleh ekosistem lamun, sehingga sangat wajar bilamana ekosistem ini memiliki nilai ekonomi yang cukup tinggi sebesar Rp. 121,75 juta per hektar per tahun. Segenap jasa ekosistem lamun yang diberikan mampu menjadi sumber kehidupan dan penghidupan yang dibutuhkan untuk memenuhi kesejahteraan masyarakat, sehingga ekosistem ini sangat memerlukan upaya pengelolaan yang baik agar tetap dapat menyediakan kebutuhan barang dan jasa yang diperlukan masyarakat pesisir dan pulau kecil. Pengelolaan ekosistem lamun seoptimal mungkin diselaraskan dengan kerangka pengelolaan sumberdaya pesisir dan laut secara terpadu dan berkelanjutan. Pendekatan pengelolaan berbasis ekosistem setidaknya memberikan kepastian adanya pemahaman bahwa ekosistem lamun adalah ikan; dan (xi) pengelolaan sampah terpadu berbasis masyarakat pesisir dan pulau kecil.

\section{Ucapan terimakasih}

Ucapan terimakasih disampaikan kepada pimpinan dan seluruh staf Pusat Kajian Sumberdaya Pesisir dan Lautan Institut Pertanian Bogor (PKSPL IPB) atas beasiswa program doktor yang telah diberikan dan segenap kesempatan untuk menggunakan akses dan fasilitas PKSPL IPB bagi penyelesaian penelitian yang dilakukan. Ucapan terimakasih juga disampaikan kepada Kementerian Ristek dan Dikti atas dana hibah penelitian Bantuan Operasional Perguruan Tinggi Negeri Tahun 2013 dan 2014 yang diketuai Dr Ir Luky Adrianto, MSc serta dukungan dana penelitian dari Pusat Unggulan Iptek Perguruan Tinggi PKSPL IPB tahun 2016. merupakan bagian dari ekosistem global yang saling berinteraksi dan memberikan pengaruh. Dan oleh karena itu, desain kebijakan pengelolaan ekosistem lamun yang disesuaikan dengan kebutuhan akan pemenuhan tujuan pembangunan berkelanjutan, yaitu keberlanjutan (ekologi), efisiensi (ekonomi) dan distribusi (sosial) diarahkan kepada beberapa kebijakan sebagai berikut: (i) penandatanganan kesepakatan bersama pengelolaan ekosistem pesisir dan laut secara terpadu dan berkelanjutan; (ii) penetapan daerah konservasi habitat lamun; (iii) penetapan zona inti (no take zone) perlindungan; (iv) pengaturan sistem zona penangkapan ikan terbatas; (v) pengembangan armada penangkapan ikan (revitalitasi kapal dan alat tangkap); (vi) pengembangan mata pencaharian alternatif (budidaya laut dan wisata bahari); (vii) pengembangan infrastruktur pemasaran produk perikanan; (viii) revitalisasi pengelolaan pasar perikanan higienis dan bertanggung jawab; (ix) pengembangan industri pakan ternak dan ikan; (x) peningkatan kapasitas dan kapabilitas sumberdaya manusia pengolah

\section{Referensi}

Adrianto, L., Kusumastanto, T., Samosir, A., Wahyudin, Y., Malikusworo, H. 2013. Pemodelan Valuasi Keterkaitan Ekosistem Lamun di Pulau Bintan. Bogor: Institut Pertanian Bogor.

Adrianto, L., Wahyudin, Y., Koropitan, A.F., Nababan, B.O. 2015. Mapping and Valuing Pelagic Ecosystem Services in the Lesser Sunda Ecoregion: Preliminary Results on the Manta Rays Pelagic Fisheries for Tourism. Paper Presented in the East Asian Seas Congress 2015. Danang, November 16-21.

Al Hadad, M.S. 2012. Valuasi Ekonomi Lamun di Pulau Waidoba Kabupaten Halmahera Selatan, Provinsi Maluku Utara. Thesis of Graduated School IPB of Natural Resources and Environmental Economics. Bogor Agricultural University. 
Batker, D. 2003. Ecosystem Service Valuation (ESV). Retrieved February 20, 2014, from Earth Economics: http://www.eartheconomics.org/Page24 .aspx

Charles, A. 2012. People, oceans and scale: governance, livelihoods and climate change adaptation in marine socialecological systems. Current Opinion in Environmental Sustainability: 4:351357.

Clark, C.W. 1985. Bionomic Modeling and Fisheries Management. New York: John Wiley \& Sons Inc.

Costanza, R. 1991. Ecological Economics : The Science and Management of Sustainability. New York: Colombia University Press.

Costanza, R., dArge, R., deGroot, R., Farber, S., Gasso, M., Hannon. 1997. The Value of the World's Ecosystem Services and Natural Capital. Nature 387: 253-260.

Costanza,R., de Groot, R., Sutton, P., van der Ploeg, S., Anderson, S.J., Kubiszewski, I., Farber, S., Turner, R.K. 2014. Changes in the global value of ecosystem services. Global Environmental Change 26: 152-158.

Cullen-Unsworth, L., Mtwana, N., Paddock, J., Baker, S., McKenzie, L., Unsworth, R. 2014. Seagrass Meadows Globally as a Coupled Social-Ecological System: Implications for Human Wellbeing. Marine Pollution Bulletin 83 : 387-397.

Dahuri, R., Rais, J., Ginting, S., Sitepu, M. 1996. Pengelolaan Sumberdaya Pesisir dan Lautan secara Terpadu. Jakarta: PT. Pradnya Paramita.

de Groot, R., van der Perk, J., Chiesura, A., and Marguliew, S. 2000. Ecological Function and Socio-economic Value of Critical Natural Capital as a Measure for Ecological Integrity and Environmental Health. In P. Crabbe, A. Holland, L. Ryszkowski, \& L. Westra, Implementing Ecological Integrity: Restoring Regional and Global Environmental and Human Health (pp. 191-214). NATO-Science Series, IV. Earth and Environmental Science Vol.1.
Dordrecht/Boston/London: Kluwer Academic Publishers.

de la Torre-Castro, M. 2006. Humans and Seagrass in East Africa - A Socialecological System Approach. Stockholm: Department of Systems Ecology, Stockholm University.

de la Torre-Castro, M., Ronnback, P. 2004. Links between Humans and Seagrasses - an Example from Tropical East Africa. Ocean Coastal Management 4:, 361-387.

de la Torre-Castro, M., Di Carlo, G., Jiddawi, N. 2014. Seagrass Importance for a Small-Scale Fishery in the Tropics: The Need for Seascape Management. Marine Polution Buletin 83: 398-347.

den Hartog, C. 1970. The Sea-grasses of the World. Amsterdam, North Holland: Verdhandelingen der Koninklijke Nederlandse Akademie van Wetenschappen, afd. Natuurkunde, Reek 2.

Dictionary. 1995. Ecosystem Services. Retrieved February 11, 2014, from Dictionary.com:http://dictionary.referenc e.com/browse/ecosystem+services.

Eliezer, A. 2001. Ecosystem - denifition from Biology Online. (R. Hasharon, Editor, \& Keebali Media) Retrieved February 15, 2014, from Biology Online: http://www.biologyonline.org/dictionary/ Ecosystem.

Fauzi, A. 2005. Kebijakan Perikanan dan Kelautan: Isu, Sintesis dan Gagasan. Jakarta: PT. Gramedia Pustaka Utama.

Fish and Wildlife Research Institute. 1999. http://myfwc.com/research/habitat/seag rasses/. Retrieved January 5, 2015, from Florida Fish and Wildlife Conservation Commision: http://myfwc.com.

Fortes, M. 1991. Seagrass-Mangrove Ecosystem Management - a Key to Marine Coastal Conservation in the Asian Region. Marine Pollution Bulletin, 23: 113-116.

Freeman III, A. 2003. The Measurement of Environmental and Resource Values. 
Washington DC: Resource for the Future.

Green, C., Tunstall, S. 1991. Is the Economic Evaluation of Environmental Resources Possible?. Journal of Environmental Management 33: 123-141.

Heck, K. J., Weistein, M. 1989. Feeding Habits of Jouvenille Reef Fishes Associated with Panamanian Seagrass Meadows. Bulletin Marine Sciences 45: 629-636.

Hughes, A., Williams, S., Duarte, C., Heck, K., Waycott, M. 2009. Associations of Concern: Declining Seagrasses and Threatened Dependent Species. Frontiers Ecology and Environment 7: 242-246.

Hutomo., Azkab. 1993. Indonesian Seagrass Resources Management, Issues and Research Priorities. In M. Moosa, H. de longh, $\mathrm{H}$. Blaauw, and M. Morimarna (Ed.), Proceeding International Seminar on Coastal Zone Management of Small Island Ecosystem, April 7-9, 1993. (pp. 119-125). Ambon: LIPI.

Hutomo, M. 1985. Telaah Ekologik Komunitas Ikan Padang Lamun (Seagrass, Anthophyta) di Perairan Teluk Banten. Bogor: Disertasi Doktor, Fakultas Pasca Sarjana IPB.

Hutomo, M., Azkab, M., dan Kiswara, W. 1988. The Status of Seagrass Ecosystem in Indonesia: Resources, Problems, Research and Management. Manila: SEAGRAM.

lizumi, H., Hattori, A., McRoy, C. 1980. Nitrate and Nitrite in Terestrial Water of Seagrass Beds, in Relation to the Rhizosphere. Journal of Experimental Marine Biology and Ecology 47: 191201.

Kiswara., Wanardi. 1994. Keanekaragaman dan Sebaran Lamun di Teluk Kuta dan Teluk Gerupuk, Lombok Selatan. (W. Kiswara, M. Moosa, dan M. Hutomo, Eds.) Jakarta: P3O-LIPI.

Kiswara, W. 1994. A Review: Seagrass Ecosystem Studies in Indonesia Waters. Bangkok: Chulalongkorn University, Bangkok Thailand.
Koesoebiono. 1995. Ekologi Wilayah Pesisir. Bogor: PPLH IPB.

Kuo, J., McComb, A. 1989. Seagrass Taxonomy, Structure and Development. (A. A.W.D. Larkum, A. McComb, \& S. Shepherd, Eds.) Amsterdam: Elsevier.

Mahifal. 2010. Kajian Potensi Pengelolaan Jasa Kelautan dan Kemaritiman Berdasarkan Undang-Undang Nomor 27 Tahun 2007 tentang Pengelolaan Wilayah Pesisir dan Pulau-pulau Kecil. Majalah IImiah Wawasan Tridharma 3: 10-19.

McKenzie, L. 2008. Seagrass Educators Handbook. Retrieved January 5, 2015, from Seagrass Watch: Local Eye, Global Wise: http://www.seagrasswatch.org/Info_cen tre/education.

Millenium Ecosystem Assessment. 2003. Ecosystem and Human Well Being Framework for Assessment. World Resources Institute. Washington: Island Inpress.

Nadiarti, Riani, E., Djuwita, I., Budiharsono, S., Purbayanto, A., and Asmus, $\mathrm{H}$. 2012. Challenging for Seagrass Management in Indonesia. Journal of Coastal Develppment 15 (3): 234-242.

Nienhuis, P. 1993. Structure and Functionning of Indonesia Seagrass Ecosystem. In M. Moosa, H. de longh, H. Blaauw, \& M. Morimarna (Ed.), Proceeding International Seminar on Coastal Zone Management of Small Island Ecosystem, April 7-9, 1993. (pp. 82-86). Ambon: LIPI.

Nontji, A. 1987. Laut Nusantara. Jakarta: Penerbit Djambatan.

Pearce, D., Turner, R. 1990. Economics of Natural Resources and the Environment. Hemel Hempstead, London: Harvester Wheat Sheaf.

Peristiwady. 1993. Note on the Fish Fauna of the Seagrass Beds at Ambon Island. In M. Moosa, H. de longh, H. Blaauw, \& M. Morimara (Ed.), Proceeding International Seminar on Coastal Zone Management of Small Island 
Ecosystem, April 7-9, 1993. (pp. 148155). Ambon: LIPI.

Peterson, G., Cumming, G., Carpenter, S. 2003. Scenario Planning: A Tool for Conservation in an Uncertain World. Conservation Biology 17 (2): 358-366.

PKSPL IPB. 1999. Perumusan Kebijaksanaan Pengelolaan Lingkungan Kawasan Padang Lamun (Seagrass Bed). Laporan Akhir (tidak dipublikasikan). Kerjasama antara Badan Pengendalian Dampak Lingkungan dan Pusat Kajian Sumberdaya Pesisir dan Lautan Institut Pertanian Bogor.

PKSPL IPB. 2012. Penyusunan Valuasi Ekonomi Sumberdaya Pesisir dan Laut Kota Bontang. Laporan Akhir (tidak dipublikasikan). Kerjasama Badan Perencanaan Pembangunan Kota Batam dan Pusat Kajian Sumberdaya Pesisir dan Lautan IPB.

Pretty, J. 2003. Social Capital and the Collective Management of Resources. Science 302: 1912-1914.

Selliers, J. D. 2001. Glossary: Ecosystem services. Retrieved February 18, 2014, from GreenFact Fact on Health and the Environment:http://www.greenfacts.org/ glossary/def/ecosystem-services.htm.

Souvorov, A. V. 1999. Marine Ecologonomics: the Ecology and Economics of Marine Natural Resources Management (Vol. 6). (A. V. Souvorov, Ed.) Zagorodnoe Shosse, Moscow, Rusia: Elsevier.

The Free Dictionary by Farlex. 2003. Ecosystem Services. Retrieved February 11, 2014, from The Free Dictionary by Farlex: http://www.thefreedictionary.com/ecosy stem+services

United Nations Environment Programme. 1993. Ecosystems and Human Well- being: A Framework for Assessment. Retrieved February 20, 2014, from Ecosystems and Their Services: http://www.unep.org/maweb/documents /document.300.aspx.pdf.

United Nations Environment Programme. 2008. Ecosystem Services | TEEB. Retrieved February 18, 2014, from The Economics of Ecosystems and Biodiversity:http://www.teebweb.org/res ources/ecosystem-services/.

Unsworth and Cullen. 2010. Recognising the Necessity for Indo Pasific Seagrass Conservation. Conservation Letters 3: 63-73.

Unsworth, R., Cullen, L., Pretty, J., Smith, D., and Bell, J. 2010. Economic and Subsistence Values of the Standing Stocks of Seagrass Fisheries: Potential Benefits of no-Fishing Marine Protected Area Management. Ocean and Coastal Management 53 (5): 218-224.

Wahyudin Y., Adrianto, L. 2012. Analisis Ekonomi Sumberdaya Alam dan Lingkungan di Selat Lombok (Economic Analysis of Natural Resources and Environment in Lombok Strait) (January 13, 2012). PKSPL-IPB Working Paper Volume 3, Number 1, January 2012 ISSN 2086-907X. Available at SSRN:http://ssrn.com/abstract=216618 7 or http://dx.doi.org/10.2139/ssrn.2166187.

Warford, J. 1989. Environmental Management and Economic Policy in Developing Countries. In G. Schramm, \& J. Warford, Environmental Management and Economic Development (pp. 7-22). Baltimore and London: The World Bank - The Johns Hopkins University Press.

Wikimedia Foundation, Inc. 2001. Ecosystem services. Retrieved February 13, 2014, from Wikipedia, the Free Encyclopedia: http://en.wikipedia.org/wik. 